Article

\title{
Towards Sustainable Mobility through a Change in Values. Evidence in 12 European Countries
}

\author{
Carlos Javier de las Heras-Rosas *(i) and Juan Herrera $\mathbb{B}$ \\ Department of Economics and Business Administration, Universidad de Málaga, 29071 Málaga, Spain \\ * Correspondence: chr@uma.es; Tel.: +34-626-564-296
}

Received: 30 June 2019; Accepted: 5 August 2019; Published: 7 August 2019

\begin{abstract}
The research carried out, as well as the measures taken to promote the use of sustainable transport in our cities, do not fully achieve their purpose. The Wertraitionalirat concept introduced by Max Weber in 1922 stated: "The use of public transport arises more from a system of values with which the person identifies than from the quality of the transport offered". This assertion made at the beginning of the 20th century is still valid, where the means, infrastructure and advances achieved do not obtain a proportional response from citizens. The aim of this work is, through this approach, to find variables that complement research on urban mobility habits. For this purpose, data from the International Social Survey Program (ISSP) and the European Social Survey (ESS) are used to analyse postmodern values and citizens' environmental awareness, linking these to sustainable mobility habits in 12 European countries. The results suggest that a higher index of postmodern values implies greater environmental awareness, which would lead to a greater use of sustainable transport, although there are variables related to environmental knowledge and risk which indicate that greater environmental education and awareness is needed.
\end{abstract}

Keywords: urban mobility; postmodernism; Europe; sustainable transport; environmental awareness; sustainability

\section{Introduction}

The World Urbanization Outlook Review published by the United Nations [1] indicates that $55 \%$ of the world's population lives in urban areas; by 2050 the United Nations projection is that this value will reach $68 \%$. In the European Union about $75 \%$ of its population lives in urban areas, a figure that rises to $80 \%$ in Organization for Economic Cooperation and Development (OECD) members. In this scenario of growing urban concentration, understanding the key trends in the urbanization of our cities, and particularly the urban mobility habits of citizens, is essential to achieve sustainable and successful development.

Planning for sustainable urban mobility has become an international concern (Sustainable Development Goal [2] The New Urban Agenda [3]), and the urgency of the necessary change has been widely discussed among academics, reflected in a high and growing body of research. However, there does not seem to be a general agreement on the best ways to achieve that change [4]. Therefore, it is a challenge that is far from simple, due to the large number of actors and determinants involved. The following paragraphs briefly contextualize the role played by the most important components in sustainable mobility and take also highlights from the lines of research that address this issue.

The urban environment has a series of characteristics that define the advantages and disadvantages that city dwellers must face. It is impossible to bring together in a single compact space the resources, activities and people that a social life requires. Today's societies are characterized by a complete specialization of space. This means that, in most cases, a large part of the daily desires and needs are not distributed in the environment close to the individual, but rather that mechanical accessibility tools 
are necessary to achieve them [5]. These instruments of mechanical accessibility are represented by the different modes of transport, among which private vehicles play a major role.

In the 1950s and 1960s, the problem of traffic in large cities was already evident. Since the first studies of urban mobility carried out in the 1950s, [6] noticed how social values, historical memories and other aspects of the individual also influenced his or her modal choice. The individual is not totally rational, he or she also possesses emotion, creativity and imagination, and these will be used by the productive market to create false needs in citizens, tying them to the system of production and consumption.

The private automobile has evolved from being a luxury article to an indispensable good, and not only due to its usefulness for what it is designed for, transporting people and goods; it also becomes a symbol of status, prestige and rational aspiration as it is considered a superior model of transport [7]. It is a common element in our life plan. The rationality of its indiscriminate use, the environmental, economic, social costs and the efficiency of the global energy system is what society in general is now concerned with, designing sustainable mobility plans for cities. It seems clear that the problem is latent. The current use of private transport far exceeds the present and future capacity of our cities. The greatest problems occur in recurrent journeys, which include all those that are repeated and routine, also called functional, because through this type of movement the functioning of a community is carried out [6].

Mobility plans drawn up and implemented by governments have focused mainly on improving and expanding the infrastructures and services available in a given population. Better modal equipment is assimilated to an improvement in the quality of life, but everything has a limit, the city becomes congested and almost paralyses its internal mobility during peak hours. The problems resulting from traffic congestion are varied. Air pollution produced by vehicles that use fossil fuels is one of the fundamental problems for a sustainable environment. To solve it we talk about the use of electric vehicles, although this proposal is not sufficient for a fully sustainable solution $[8,9]$. The problems of space, parking, noise pollution and lack of road infrastructure are not solved by the use of electric vehicles. In addition, we must add the growing number of injuries and accidents in urban environments, reflected in rising medical and economic costs [10].

\subsection{The City and the Car}

The city is articulated according to motorised mobility and the geographical distribution of the population, where citizens share spaces and housing buildings at a greater or lesser distance from their work or study centres. This leads to an exponential increase in urban travel. The effects of transport networks on urban environments, as well as on their social and economic structure, were already studied by Cooley [11] in The Theory of Transportation. However, in the old urban centres (especially in Europe) the original design of the city conditioned the networks and transport models that would arrive later. The accelerated and disorderly growth of the population made necessary a series of notable changes in the form of widening avenues and walks open to traffic, and cities began to be structured with mobility in mind [12]. The modern city acquires a series of characteristics linked to economic progress and the incessant advance of motorised journeys. The American model is based on grid-shaped cities with large avenues ready for traffic. In Europe and in many cases as a result of medieval heritage, the starting point is different, although the same end is pursued. Paris became a model to follow in the old continent, with wide boulevards and roundabouts designed for road traffic, trams and vehicles taking over the city. Halbawchs [13], the Haussmann Plan in Paris [14], Cerdá in Barcelona [15], Howard and the concept of the Garden City [16,17], represent examples of the growth and planning of cities that has taken place since the beginning of the 20th century.

The city needs "automobility" [18], as it requires a spatial structure so that it can circulate, to park and to move around. The current urban environment has been built in most cases during the second half of the twentieth century to adapt to the use of the car. Workplaces have been separated from 
residences and vice versa, pedestrians and cyclists have been moved from the road, and leisure and commercial places have been generated where it is only possible to go by motorised means.

Freud and Martin [19] articulate how modern urban spaces were constructed to facilitate the automobility defined by Urry, to the detriment of other forms of personal movement, filling the world with dead spaces designed for cars. In London, a quarter of the space occupied by the city is intended for the automobile, rising to half in the case of the city of Los Angeles. Parking lots, roads, bridges and other infrastructures have been designed to accommodate the automobile, which is also a symptom of progress in modern societies.

The arrival of the automobile in the city implied changes that society assumed. In the second decade of the twentieth century, the inhabitants of cities called citizens became pedestrians, the car seized the center of the roadway, the pedestrian could no longer walk where he wanted, and could not cross anywhere. The car has displaced the bicycle and the citizens [20]. The eruption of bicycle lanes and pedestrianization of the center in some cities are timidly reversing the situation in certain areas, but much remains to be done.

\subsection{Sustainable Urban Mobility}

The degree of remoteness from the dwelling to the city centre, or from the main activity of the citizen, is composed of a conjunction of variables such as distance and time, the cost of transport and the income of that subject [21]. This study by Alonso, would be validated in the 1970s by Yacob Zahavi, who exposes how the time that the population devotes to its displacements tends to be constant; the better and faster the means available to move, the further we will move and the further we will locate our place of residence [22]. The geographical location of dwellings, work centres, places of study and family dwellings, among others, configures the complex and extensive metropolitan order, where punctuality, calculability and accuracy are demanded [23]. In this regard, Banister [24] adds how the increase in individual well-being could lead to an increase in the number of kilometres travelled. For the author, the conventional paradigm of minimizing travel time by increasing speed is unsustainable, considering that action could be taken to somehow reduce the need to travel.

Urban spaces, collective transport offers, the built environment, lifestyles, demographics, energy systems and other conditioning factors make up each city. The transport policies that are carried out and the approach to routes and itineraries have shown that the old model based on supply and demand is insufficient, where the choice made by each individual does not correspond sufficiently with the approaches made from higher levels. The need for a shift towards sustainable mobility and optimisation of available resources has generated a significant number of research and scientific projects in this area. The problem addressed is not a simple one, as there are many agents involved and the necessary conditions for the change sought are complex [25-28]

In research on planning for sustainable urban mobility and accessibility, several main themes arise: urban form, modes of transport and their combination, planning for accessibility and the local context. On the importance of urban form and in the search for traditional urban planning, Cervero and Kockelman define three main dimensions. density, diversity and design [29], high density, diversity of land use and city design will make motorised travel more or less favourable. Subsequently, in 2002, Cervero added four more dimensions to the original three: accessibility to the destination, distance to travel, demand management and demography [30]. The importance of the local context in the planning of sustainable urban mobility is beginning to be addressed in some way.

Kenworthy [31] and Banister's subsequent works go one step further by arriving at the principles of the sustainable mobility paradigm; where four principles are identified: making better use of technology, regulating and pricing, developing the distribution of spaces and clearly oriented personal information [25] (pp. 78-79).

Another of the most prolific authors in the search for sustainable solutions for urban transport is Bertolini [32], who advocates multimodality, combining different modes of transport and including among them the private vehicle and others not previously foreseen. The author argues that the correct 
distribution of available space in cities for the different modes of transport, the education of citizens and appropriate policies represent a further step in the sustainable planning sought. Examples such as the integration of bicycles into a city's transport offer, as has happened in the United Kingdom and some Spanish cities (Malaga, Madrid, Barcelona), point to the importance of this approach.

In 2011, Banister [33] further develops the concept of sustainable urban mobility, stressing the importance and urgency of change, adding the role of governments as a fundamental tool in the intended purpose. This coincides with the works of Vergragt and Brown in 2007 [34] and Zhao in 2010 [35] which point out that governments must play a transcendental role in the search for sustainable mobility: stimulating and applying technological innovation, encouraging research, investing in infrastructures, providing leadership and organizing and leading a debate with a global approach to the problem, serving as a visible head in the measures and development of sustainable mobility. Along these lines, Hull [36] suggests that an agreement is needed between all the public sectors involved, aligning strategies that encourage the general public to use sustainable transport, providing legal and financial support for the achievement of joint projects between the parties involved and the authorities. Case studies carried out by Hysing in a Swedish population [37], or by Buehler and Pucher [38] in Germany, confirmed the importance of policy decisions to achieve change towards sustainable mobility.

Transport systems are complex and cannot be isolated from the city's infrastructure, energy systems and urbanization, even from the city's climate. Several studies have suggested methodologies for modelling transport systems with respect to their environment [39-43], however no single methodology has been achieved that is accepted by all [4]. Globalization brings shared technology and knowledge, from the European Union and international organizations are promoted projects and policies in post of a sustainable mobility, the problem lies in the transfer of these policies at the local level. The influence of the local environment makes it difficult to design transport policies that are applicable to different regions [44,45].

\subsection{Objectives and Hypotheses of the Research}

The study of transport models, spatial planning and organisation of cities should not be approached only from the usual economic and technical approaches, which although they represent a considerable advance with the help of powerful computer tools and the new connectivity, do not fully explain the phenomenon. To achieve change towards sustainable mobility, institutional, financial, legislative, political, technical and cultural barriers must be overcome [46]. Other points of view more related to the individual who makes the decisions should also be taken into account [47-49].

This document provides a complementary approach to studies on sustainable mobility in urban areas, focusing on the influence of the individual's values and environmental awareness regarding the choice of mode of transport. The research and policies carried out to improve the mobility of our cities start from different disciplines that complement each other and pursue a common objective: to achieve sustainable, safe, energy-efficient and environmentally friendly mobility.

The research and projects that are being carried out have an impact on this problem, and sustainable mobility is an issue that is on the table in most transport policies in developed countries. Citizens' lifestyles are settling over time, just as technological changes and new mobility solutions are entering more or less quickly people's habits, but not everything is instantaneous. Intelligent mobility is presented as one of the main options for more sustainable transport [50]; real-time management of car parks, means of transport, vehicle management for sharing include other options [51], and even the irruption of new vehicles with alternative and/or electric fuels [52], need adaptation and public awareness: a change of values. The population must be re-educated in this respect. The key question has already been asked: how can we get more people to travel by public transport in a region where most people prefer to travel by car? [53].

This research delves into other variables that influence the modal choice of the individual. The analysis focuses on the influence of a society's modern/postmodern values of a society have on 
the consciousness and pro-environmental behavior of individuals, and thus its involvement in urban mobility habits.

It is not the objective of this article to go into the stages and passage from modernism to postmodernism in some societies, but to point out that a significant change of values has been generated more strongly in some countries with respect to others since the middle of the 20th century [54-56]. For more than four centuries, modernity represented the power of reason and logic, as opposed to traditional values or those imposed by authority. It is a stage where reason imposes itself on religion and through legislation the freedoms and rights of citizens are protected. Productive processes are industrialized and society emerges with new, more prosperous social classes. It is a stage of unstoppable progress and permanent change, but after several revolutions and two world wars in the twentieth century, the world is segmented and pessimism takes over much of society, the ideal model had failed. Modernity has been languishing since the middle of the last century [57].

In the 1970s, Ronald Inglehart, among other authors, deepened and developed the concept of postmodernity. After two world wars, the segmentation of the world, pessimism and the clash of cultures, the paradigm of modernity has languished since the middle of the 20th century [58]. Postmodernism is the birth of new values and lifestyles, and implies greater tolerance for ethnic, cultural and sexual diversity, as well as individual choices concerning the type of life one wants to lead. Among other changes, and those most related to the article presented, postmodern values correspond to a more secure society from the political and economic point of view and are no longer associated with a past of scarcity. This fact has led to a disproportionate consumption of resources in postmaterialist society, which has produced severe environmental degradation, which is worse in the poorest countries. The citizen has more information and is more aware of the protection of the environment [59]. Quality of life is the highest priority, involvement in ecological problems, the defence of a sustainable way of life, and the search for well-being are characteristic aspects of this paradigm [58].

The advance of societies from modernism to postmodernism is inevitable in the globalized world, although some do so before others. If postmodern societies maintain a greater concern for the environment, and this translates into a more pronounced environmental attitude and behaviour, one might think that this relationship would lead to a greater use of sustainable transport. The two main hypotheses presented in this research are the following:

\section{H1. A more postmodern society implies a greater environmental awareness of its citizens.}

H2. Greater environmental awareness and behaviour implies greater use of sustainable transport.

In order to examine the incidence of these postmodern value variables on environmental awareness and sustainable transport, the unit of analysis must be the country. Both postmodern values and environmental awareness are indicators that can vary little within a state, but if they can vary significantly from one state to another, in this way one chooses to compare data from different countries at a given time.

Through two surveys carried out in 12 European countries in the same period of time, the possible correspondence between postmaterialistic values and environmental awareness [60] and the possible relationship between environmental awareness and sustainable mobility habits will be analysed. Comparison in 12 European states allows these variables to be related to the modal choice of their citizens. In this way, environmental and postmodern values provide an approach that complements the complex analysis of the conditioning factors for achieving sustainable mobility within cities. The aim of this document is to highlight the direct influence that social values relating to modernism/postmodernism and environmental awareness have on mobility habits, where it will be demonstrated that more postmodern societies with more developed environmental awareness and attitude are to a greater extent consumers of sustainable transport options, although with some nuances that will be developed later. 


\section{Materials and Methods}

Europe becomes the ideal setting for this research. The European Union has repeatedly indicated the need to adapt cities, the economy and lifestyles to a culture of sustainable mobility. The European Union's Transport White Paper, both in its 1995, 2001 and 2011 editions, proclaims the need for transport policies that are sustainable and competitive. The countries chosen for this research belong to the European Union. The sharing of laws, guidelines and regulations related to the subject matter of this research makes the results comparable and conclusive in a more accurate way.

The data used in this research come from two statistical studies of international prestige: the International Social Survey Programme ISSP 2010 "Environment III"; and the Special Eurobarometer 406-79.4. There are other options with available data, such as the World Values Survey (WVS), which also includes questions on the environment and modernism/postmodernism but has not been used because of the low representation of European Union countries it contains. Other available surveys from the European Union, such as the Eurobarometer or the European Values Study, include data referring to urban mobility or the environment, but do not coincide in the same survey, so they did not meet one of the parameters sought in this project.

The complete methodology used in conducting the surveys is available in the links that can be found in the bibliography of this manuscript [61,62]. The two methods are based on random sampling in several stages, starting with primary sampling units (PSU) subdividing each country into different zones; in the second stage a group of addresses is selected for each PSU sampled, proportional to the size of each population.

With the data extracted from the surveys, a total of 24 variables will be obtained, 13 from ISSP Environment III (M1 and A1 to A12) and 11 from Eurobarometer 406-79.4 (H1 to H5 and P1 to P6). Two indicators will be obtained from these variables, the percentage difference index (PDI) to measure modernism/postmodernism and the sustainable transport index (STI) to measure the use of sustainable transport. The rest of the variables are independent and will be used for the bivariate correlations with the indices obtained (PDI and STI).

Therefore, once each variable and index is weighted, countries are scored by a percentage per variable according to what their citizens have answered. The methods used are described in more detail in the following paragraphs.

The use of the two surveys chosen allows us to analyse the three key aspects for this research: modern/postmodern values, environmental awareness and urban mobility habits in as many European countries as possible. Ideally, each respondent would have answered all the questions needed in this analysis, but no surveys have been found that link the three aspects commented on in the same questionnaire. What is available is a survey linking modern/postmodern values with environmental awareness (ISSP: Environment III) and another survey linking urban mobility habits with environmental awareness (Eurobarometer 406-79.4). In this way and in two simple steps we will obtain the necessary information for the analysis we are looking for. The choice of countries analyzed has depended on the databases chosen for the purposes of this research. The two surveys and their relationship to the hypotheses are as follows (Figure 1):

- For hypothesis H1: data available from the International Social Survey Program (ISSP) Environment III will be used [61]

- For hypothesis H2: the data available in the European Social Survey (ESS) Eurobarometer 406-79.4 will be used [62]

At the time of this research, the ISSP Environment III included 32 countries from all over the world, of which 16 were European. The ESS Eurobarometer 406-79.4 includes the 28 countries of the European Union. In order to compare the same companies, the 16 countries available in the ISSP Environment III are used. The 16 countries initially available are: Austria (AT), Belgium (BE), Bulgaria (BU), Croatia (HR), Czech Republic (CZ), Denmark (DK), Finland (FI), France (FR), Germany (DE), Lithuania (LT), Latvia (LV), Slovak Republic (SK), Slovenia (SI), Spain (ES), Sweden (SE) and Great 
Britain (GB). The nations of Lithuania, Latvia and Slovenia have much smaller population sizes than the rest and are discarded for this reason. Austria is also discarded because of its cultural proximity to neighbouring countries that are included. In future studies, provided that comparable data exist, it would be appropriate to add to the elected societies the rest of the European Union countries and even nations from other continents.

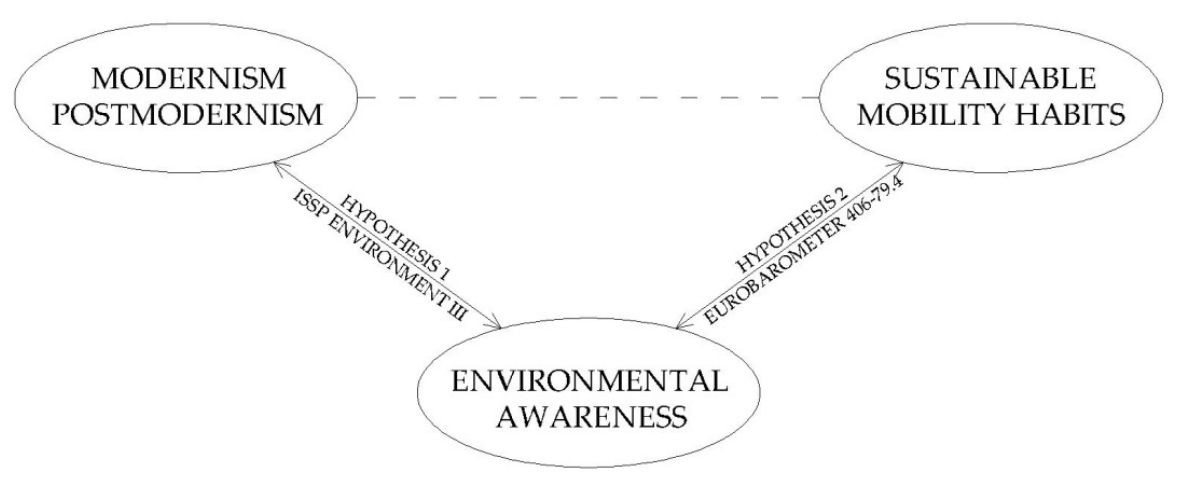

Figure 1. From postmodern values to sustainable mobility. Source: Own preparation.

In the sample of the 12 countries chosen, a geographical continuity is maintained between north-south, east-west, at the same time as societies with greater and lesser degrees of development are included, as well as old and new democracies. Thus, the results obtained should show a more varied range of values, a fact that is always advisable in social studies. The countries chosen are: Belgium (BE), Bulgaria (BU), Croatia (HR), Czech Republic (CZ), Denmark (DK), Finland (FI), France (FR), Germany (DE), Slovak Republic (SK), Spain (ES), Sweden (SE) and Great Britain (GB) Figure 2.

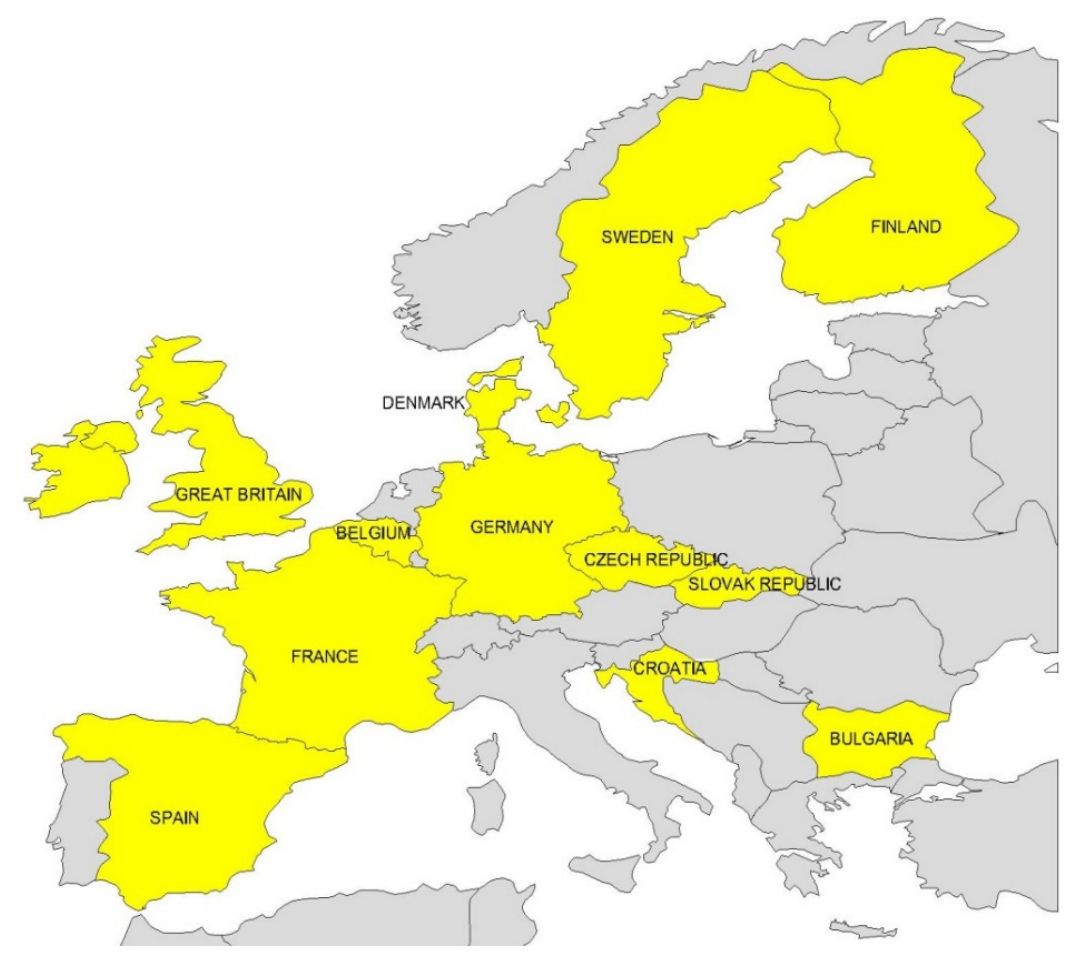

Figure 2. Countries chosen in the research. Source: Own preparation.

\subsection{Postmodern Values and Environmental Awareness. Materials for Hypothesis H1}

For the analysis of the relationship between a society's postmodern values and its environmental consciousness, the survey conducted by the International Social Survey Programme (ISSP) in 2010, called ISSP 2010: Environment III, will be used [61]. 
The ISSP Environment III dedicates its 2010 wave of study to Attitudes to Environmental Protection. This survey is conducted in 32 countries around the world, where people over 18 years of age are interviewed (in Finland over 15 years of age). The main blocks of this survey are:

- Most important issues for your country;

- Those responsible for economic problems;

- Inglehart postmaterialism Scale (4 items);

- Materialistic and postmaterialistic attitudes;

- Concern and habits regarding environmental problems;

- Responsible for environmental problems;

- Energy sources;

- Demographic data;

- Activity, policy orientation and others.

Table 1 shows the number of surveys conducted in each chosen country.

Table 1. Characteristics of the International Social Survey Programme (ISSP) 2010 sample of 12 selected countries.

\begin{tabular}{cccc}
\hline Country & No. of Surveys & Country & No. of Surveys \\
\hline Belgium & 1142 & France & 2253 \\
Bulgaria & 1003 & Germany & 1407 \\
Croatia & 1210 & Slovakia & 1159 \\
Czech Republic & 1428 & Spain & 2560 \\
Denmark & 1305 & Sweden & 1181 \\
Finland & 1211 & United Kingdom & 928 \\
\hline Total & 16,787 \\
\hline
\end{tabular}

Source: Own elaboration through ISSP 2010 “Environment III” ISSP Research Group.

The Inglehart Postmaterialism Scale developed in the 70s of the 20th century is included within the thematic blocks contained in the ISSP Environment III. This scale is the most valid and best documented indicator to measure the dimension of modernization/postmodernization in a society. This indicator has been used by numerous authors and organizations since its creation. Inglehart in 1971, 1976 and 1977 through the then European Economic Community, and the European Social Survey (EVS), the World Values Surveys (WVS) among others have been making this assessment of countries, which in their last waves covered $75 \%$ of the world population [63]. The scale is made up of two consecutive questions where respondents are told to choose which should be the first priority for their country and the second, choosing from four available items. The choices are as follows:

- Maintain the order of the nation;

- Increasing citizens' participation in important government decisions;

- Combat the rise in prices;

- Protect freedom of expression.

If the respondent chooses the first and third option ( 1 and 3 , or 3 and 1 , the order does not matter) it would represent a materialistic orientation, or in other words, less postmodern. On the other hand, if you choose the second and fourth option ( 2 and 4 , or 4 and 2, the order does not matter), it would represent a postmaterialistic orientation, which resembles postmodern values. In cases where their choice is crossed ( 1 and 2, 1and 4, 2 and 1,2 and 3,3 and 2, 3 and 4, 4 and 1, 4 and 3), we speak of a mixed orientation. The scale has lasted without significant criticism that has forced changes in the composition or disposition of the answers. The choice of citizens as to what they consider to be the most important priorities for their country, choosing them from among four possibilities, allows us to obtain the PDI for each country, which is explained below. 
The survey conducted by ISSP 2010: Environment III, consists of more than 50 questions, although the number of questions varies slightly depending on the country where the survey has been conducted, the questions drawn from the questionnaire conducted in ISSP 2010 are common in all selected countries. The questions used for this study of the ISSP Environment III survey are shown in Table 2, together with the name of the variable, the question number of the questionnaire and the statement of the question.

Table 2. Classification of variables ISSP 2010: Environment III.

\begin{tabular}{|c|c|c|c|}
\hline Model & Variable & No. & Question \\
\hline Postomdernist Values & M1 & $\begin{array}{l}3 a \\
3 b\end{array}$ & Postmaterialism Scale Inglehart (4 Ítems) \\
\hline \multirow{5}{*}{$\begin{array}{c}\text { Environmental } \\
\text { Awareness }\end{array}$} & A1 & 6 & Level of environmental concern \\
\hline & $\mathrm{A} 2$ & $10 \mathrm{a}$ & Concern for the environment and not for prices and employment \\
\hline & A3 & $12 \mathrm{a}$ & Willingness to pay high prices \\
\hline & A4 & $12 b$ & Willingness to pay more taxes \\
\hline & A5 & $12 \mathrm{c}$ & Willingness to lower standard of living \\
\hline \multirow{3}{*}{$\begin{array}{l}\text { Environmental } \\
\text { Knowledge }\end{array}$} & A6 & $14 a$ & Environmental hazard perception by car \\
\hline & A7 & $14 \mathrm{~b}$ & Perception of environmental hazard by industries \\
\hline & A8 & $14 \mathrm{c}$ & Perception of environmental hazard by agricultural chemistry \\
\hline \multirow{4}{*}{$\begin{array}{c}\text { Pro-environmental } \\
\text { behavior }\end{array}$} & A9 & $20 \mathrm{a}$ & Recycling frequency in the home \\
\hline & A10 & $20 \mathrm{~b}$ & Frequency of purchase of organic products \\
\hline & A11 & $20 \mathrm{c}$ & Frequency of not using the car for environmental reasons \\
\hline & A12 & 21 & Belonging to an environmental group or organization \\
\hline
\end{tabular}

The variables extracted from this survey are: M1 (Postmaterialism-PDI); A1, A2, A3, A4 and A5 (Environmental awareness); A6, A7 and A8 (Environmental knowledge); A9, A10, A11 and A12 (Pro-environmental behaviour). In total there are 16,787 valid cases.

\subsection{Environmental Awareness and Sustainable Mobility Habits. Materials for Hypothesis H2}

The second source used comes from Eurobarometer 79.4, which in 2013 [62], during the months of May and June, carried out a survey in which, among other thematic blocks, it dedicated a large part to public transport and environmental aspects. The 79.4 wave of Eurobarometer 406 was called Social Climate, Development Aid, Cyber Security, Public Transport, Anti-microbial Resistance and Space technology. The survey is carried out in 29 countries, for a total of 27,680 cases. For this part of the research, the same 12 countries used previously were chosen. Table 3 shows the number of surveys per country and the entity that conducted the survey in each case.

Table 3. Sample characteristics from 12 selected countries Eurobarometer 406-79.4.

\begin{tabular}{cccc}
\hline Country & No. of Surveys & Country & No. of Surveys \\
\hline Belgium & 1006 & France & 1053 \\
Bulgaria & 1025 & Germany & 1003 \\
Croatia & 1000 & Slovakia & 1000 \\
Czech Republic & 1026 & Spain & 1008 \\
Denmark & 1010 & Sweden & 1000 \\
Finland & 1003 & United Kingdom & 1006 \\
\hline Total & \multicolumn{4}{c}{12,140} \\
\hline \multicolumn{4}{c}{ Source: Own elaboration through Eurobarometer 406-79.4. }
\end{tabular}

The Eurobarometer 406-79.4 survey is structured in 6 thematic blocks (A, B, C, D, E and F). The fourth block (D), the most important for this research, deals with urban mobility habits and the environment through 8 multiple questions. The interview closes with the sociodemographic aspects of the interviewee. Supplementary Materials of this document reproduce the questionnaire relating 
to urban mobility and other questions of interest. The interest of this survey for the research is that in the same questionnaire it will be possible to relate sustainable mobility habits and environmental awareness. The variables extracted from this survey are reflected in Table 4.

Table 4. Classification of variables Eurobarometer 406-79.4.

\begin{tabular}{cccc}
\hline Model & Variable & No. & Question \\
\hline \multirow{4}{*}{ Mobility Habits } & H1 & QD15 & Frequency of walking \\
& H2 & QD11 & Frequency of going by car \\
& H3 & QD13 & Frequency of riding a motorcycle \\
& H4 & QD12 & Frequency of going on public transport \\
& P1 & QD5 & Frequency of cycling \\
\hline \multirow{4}{*}{ Environmental } & P2 & QB6 & EU priority on climate change \\
Awareness & P3 & QD4 & EU priority on the environment \\
& P4 & QD4 & Perception of traffic jams as an urban problem \\
& P5 & QD4 & Perception of air pollution as an urban problem \\
& P6 & QD8 & Citizens as Responsible Reduce Traffic in Cities \\
\hline
\end{tabular}

Source: Own elaboration.

The variables extracted from the Eurobarometer 406-79.4 survey are composed of two groups. On the one hand: $\mathrm{H} 1, \mathrm{H} 2, \mathrm{H} 3, \mathrm{H} 4$ and $\mathrm{H} 5$, from which the STI explained in the following paragraphs will be extracted, and on the other hand, the variables P1, P2, P3, P4, P5 and P6 are obtained to evaluate environmental awareness.

\subsection{Methods}

\subsubsection{Weighting of Variables}

All the responses obtained through the surveys carried out in the 12 companies studied have been subjected to a weighting process based on 100, thus achieving homogeneity in the results of the available data. For example, in question 12a of ISSP2010, variable A3, this would be the case: Question 12a (variable A3).

How willing would you be to pay much higher prices in order to protect the environment?

The possible answers are:

- Very willing

- Fairly willing

- Neither willing nor unwilling

- Fairly unwilling

- Very unwilling

- Can't choose

Table 5 details the process.

Table 5. Variable weighting (variable A3: Pay higher prices in order to protect the environment).

\begin{tabular}{cccccccc}
\hline Country & $\begin{array}{c}\text { Very } \\
\text { Willing }\end{array}$ & $\begin{array}{c}\text { Fairly } \\
\text { Willing }\end{array}$ & $\begin{array}{c}\text { Neither Willingnor } \\
\text { Unwilling }\end{array}$ & $\begin{array}{c}\text { Fairly } \\
\text { Unwilling }\end{array}$ & $\begin{array}{c}\text { Very } \\
\text { Unwilling }\end{array}$ & $\begin{array}{c}\text { Can't } \\
\text { Choose }\end{array}$ & $\begin{array}{c}\text { Total } \\
\text { Cases }\end{array}$ \\
\hline $\begin{array}{c}\text { España } \\
\text { España (weighting } \\
\text { in base 100) }\end{array}$ & 36 & 595 & 641 & 735 & 448 & 0 & 2495 \\
\hline
\end{tabular}

Source: Own elaboration through ISSP 2010. 
Thus, it could be said that $26.8 \%$ of those surveyed in Spain would be very much in favour or quite a lot in favour of paying higher prices for environmental protection. It is not intended to imply that respondents are fully representative of the country specified, but does provide useful information in comparison with the other countries chosen.

The set of responses obtained in each country in the sample has been previously weighted with respect to the age variable, since in the study of modernist/postmodernist values, as well as in aspects related to environmental awareness and urban mobility habits, the age of the respondent has a greater or lesser impact on the values obtained $[54,58,64,65]$. The age weighting (Appendix A) has been carried out directly on the page where the survey resides, by means of tools provided for this purpose.

\subsubsection{Postmaterialism Index (Percentage Difference Index, PDI)}

The post-materialism index in the 12 European countries is obtained by operating the data obtained from the ISSP 2010 Environment III survey. The so-called PDI $[54,66]$ will be used. It is the most recommended and accepted for the analysis of several societies in comparison, is obtained by subtracting the percentage of post-materialists reached, the percentage obtained from materialists. This indicator is equivalent to an average score ranging from -100 (totally materialistic) to 100 (completely postmaterialistic). The case of Germany is shown in Table 6.

Table 6. Calculation of the postmaterialism index variable M1 (Ej. Germany).

\begin{tabular}{|c|c|c|}
\hline Highest Priority in Your Country & Next Highest Priority in Your Country & Germany \\
\hline \multirow{4}{*}{1 Maintain order in the nation } & 1 Maintain order in the nation & 2.3 \\
\hline & 2 Give people more say in government decisions & 10.7 \\
\hline & 3 Fight rising prices & 6.8 \\
\hline & 4 Protect freedom of speech & 8.6 \\
\hline \multirow{4}{*}{$\begin{array}{l}2 \text { Give people more say in } \\
\text { government decisions }\end{array}$} & 1 Maintain order in the nation & 12.3 \\
\hline & 2 Give people more say in government decisions & 4.4 \\
\hline & 3 Fight rising prices & 11.1 \\
\hline & 4 Protect freedom of speech & 14.6 \\
\hline \multirow{4}{*}{3 Fight rising prices } & 1 Maintain order in the nation & 4.1 \\
\hline & 2 Give people more say in government decisions & 4.2 \\
\hline & 3 Fight rising prices & 1.1 \\
\hline & 4 Protect freedom of speech & 2.5 \\
\hline \multirow{4}{*}{4 Protect freedom of speech } & 1 Maintain order in the nation & 5.7 \\
\hline & 2 Give people more say in government decisions & 9.1 \\
\hline & 3 Fight rising prices & 1.2 \\
\hline & 4 Protect freedom of speech & 1.4 \\
\hline \multicolumn{2}{|c|}{ Materialists: $(1$ and 3$)+(3$ and 1$)$} & 10.9 \\
\hline \multicolumn{2}{|c|}{ Postmaterialists: $(2$ and 4$)+(4$ and 2$)$} & 23.7 \\
\hline \multicolumn{2}{|c|}{ Mixed: $(1$ and 2$)+(1$ and 4$)+(2$ and 1$)+(2$ and 3$)+(3$ and 2$)+(3$ and 4$)+(4$ and 1$)+(4$ and 3$)$} & 56.3 \\
\hline \multicolumn{2}{|c|}{ Percentage Difference Index (PDI) } & 12.8 \\
\hline
\end{tabular}

Source: Own elaboration through ISSP 2010.

\subsubsection{Sustainable Transport Index (STI)}

In order to construct the sustainable transport index by country, we use Eurobarometer 406-79.4, which is the reference survey for this part of the research. For sustainable transport, we count those journeys made by public transport, bicycle or on foot. Those that are not sustainable are those made in private vehicles of the individual, car or motorbike (those journeys made in non-fossil fuel vehicles, which although sustainable for the environment, do not improve traffic congestion problems in cities and have not been included due to a lack of information). The index will be constructed by default, i.e., it will calculate what percentage of respondents use their car or motorbike infrequently so that countries with a higher calculated index will mean that their citizens have more sustainable mobility habits. 
To construct the STI is as follows: it will calculate how many respondents have answered that they use the car in the options shown in italics;

- Several times a day

- Once a day

- Two or three times a week

- Once a week

- Two or three times a month

- Less frequently

- Never

It is understood that as daily mobility, there would be options: several times a day, once a day, or even two or three times a week. Therefore, the answers are chosen for the index: once a week, two or three times a month, less frequently or never. In this way we are selecting all the citizens who do not use the car (neither as their own vehicle, nor as accompanied), or who in the case of using it, only use it once a week as the most frequent mode. The selected individuals practice sustainable mobility, but there remains another vehicle that is catalogued as unsustainable: the motorcycle.

From the group of citizens previously chosen from the car question, and in each category of the four available in italics, those will also be selected who, in relation to motorcycle travel, choose once a week, two or three times a month, less frequently or never. As an example, Belgium, Table 7 gives:

Table 7. Elaboration of sustainable transport index (STI), Belgium.

\begin{tabular}{|c|c|c|c|c|}
\hline Frequency of Use of Car & & \multicolumn{2}{|c|}{ Frequency of Use of Motorbike } & $\begin{array}{c}\text { Index Partial } \\
\text { Sustainable Transport }\end{array}$ \\
\hline Once a week & $6.9 \%$ & $\begin{array}{c}\text { Once a week } \\
\text { Two or three times a month } \\
\text { Less frequently } \\
\text { Never }\end{array}$ & $\begin{array}{l}0.0 \% \\
0.0 \% \\
0.1 \% \\
6.4 \%\end{array}$ & $6.5 \%$ \\
\hline Two or three times a month & $4.4 \%$ & $\begin{array}{c}\text { Once a week } \\
\text { Two or three times a month } \\
\text { Less frequently } \\
\text { Never }\end{array}$ & $\begin{array}{l}0.0 \% \\
0.0 \% \\
0.1 \% \\
4.0 \%\end{array}$ & $4.1 \%$ \\
\hline Less frequently & $3.7 \%$ & $\begin{array}{c}\text { Once a week } \\
\text { Two or three times a month } \\
\text { Less frequently } \\
\text { Never }\end{array}$ & $\begin{array}{l}0.0 \% \\
0.0 \% \\
0.1 \% \\
3.5 \%\end{array}$ & $3.6 \%$ \\
\hline Never & $8.4 \%$ & $\begin{array}{c}\text { Once a week } \\
\text { Two or three times a month } \\
\text { Less frequently } \\
\text { Never }\end{array}$ & $\begin{array}{l}0.0 \% \\
0.1 \% \\
0.0 \% \\
7.9 \%\end{array}$ & $8.0 \%$ \\
\hline Total that they don't use the car much & $23.8 \%$ & Sustainable Transport Inde & (STI) & $22.2 \%$ \\
\hline
\end{tabular}

Source: Own elaboration through Eurobarometer 406-79.4 (2013).

\subsubsection{Correlation Analysis between Variables}

In addition to the descriptive statistics of each country, to analyze the possible relationship between postmodern values and environmental consciousness, as well as the possible relationship between mobility habits and environmental consciousness, bivariate correlations, based on Pearson's linear correlation coefficient, will be used. Two surveys (ISSP 2010: Environment and Eurobarometer 406-79.4) have been used. The PDI has been extracted from ISSP2010 to measure modernism/postmodernism, and the STI has been constructed from Eurobarometer 406-79.4. Each of these indices will be associated by means of a two-dimensional statistical analysis with the rest of the variables of its own survey. In other words, the PDI is paired with variables A1 to A12, and the STI with variables P1 to P6. 
From the bivariate correlation, the variance and the covariance will be extracted, from which the Pearson correlation coefficient will be obtained (it takes values between -1 and 1 , where values close to 1 or -1 indicate a possible correlation between the variables): The covariance and the Pearson linear correlation coefficient between variables. If the value obtained in the pairings for bilateral Significance (Bilateral Sig.) is less than 0.05 or even less than 0.01 , it can be affirmed with a risk of error of 0.05 or 0.01 that both chosen variables are related and there is significant correlation. The statistical calculations have been carried out with the SPSS computer application.

The grouping carried out in the variables of the two surveys will allow us to deduce whether environmental awareness and attitude are related to the postmodern values of a society, and if so, whether those postmodern values imply a greater use of sustainable transport. As discussed in this paper, the shift in values towards postmodernism leads to a greater concern for the environment and ecology, a greater interest in the common welfare and the community, which leads us to think about more sustainable transport practices. The summary of variables and groupings is shown in Table 8 below.

Table 8. List of research variables.

\begin{tabular}{|c|c|c|}
\hline Source & Variable & Indicator \\
\hline \multirow{4}{*}{ 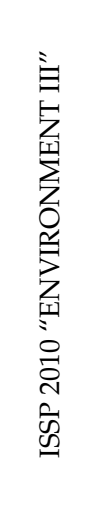 } & M1: Postmaterialism index (PDI) Inglehart 4 items & PDI Postmaterialism \\
\hline & $\begin{array}{l}\text { A1: Level of environmental concern } \\
\text { A2: Greater concern for the environment rather than prices or employment } \\
\text { A3: Willingness to pay higher prices for protecting the environment } \\
\text { A4: Willingness to pay more taxes for environmental protection } \\
\text { A5: Willingness to lower the standard of living for the protection of the environment }\end{array}$ & $\begin{array}{l}\text { Environmental } \\
\text { awareness }\end{array}$ \\
\hline & $\begin{array}{c}\text { A6: Environmental hazard perception by car } \\
\text { A7: Perception of environmental hazard by industry } \\
\text { A8: Perception of danger to the environment from agricultural chemicals }\end{array}$ & $\begin{array}{l}\text { Environmental } \\
\text { knowledge }\end{array}$ \\
\hline & $\begin{array}{l}\text { A9: Recycling frequency in the home } \\
\text { A10: Frequency buy ecological products } \\
\text { A11: Frequency do not use car for environmental reasons } \\
\text { A12: Belonging to an environmental group }\end{array}$ & $\begin{array}{l}\text { Pro-environmental } \\
\text { behaviour }\end{array}$ \\
\hline \multirow{2}{*}{ 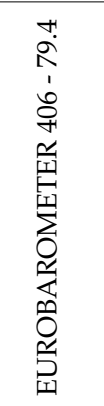 } & $\begin{array}{l}\text { H1: Walking frequency } \\
\text { H2: Frequency of going by car } \\
\text { H3: Frequency of riding on motorcycle } \\
\text { H4: Frequency of going on public transport } \\
\text { H5: Frequency of cycling }\end{array}$ & $\begin{array}{c}\text { Sustainable Transport } \\
\text { Index (STI) }\end{array}$ \\
\hline & $\begin{array}{l}\text { P1: EU priority climate change } \\
\text { P2: EU environment priority } \\
\text { P3: Perception of traffic jams as an urban problem } \\
\text { P4: Perception of noise pollution as an urban problem } \\
\text { P5: Perception of air pollution as an urban problem } \\
\text { P6: Responsible for reducing traffic in cities }\end{array}$ & $\begin{array}{l}\text { Environmental } \\
\text { awareness }\end{array}$ \\
\hline
\end{tabular}

\section{Results}

The 15,402 valid cases recorded in the 12 countries, $31.1 \%$ of respondents demonstrate materialistic values, while $9.6 \%$ do so with post-materialistic values; $57.3 \%$ are mixed. The chosen sample of 12 European societies offers the possibility of contrasting how different cultures and societies present different values. The results are shown in Table 9. 
Table 9. Materialistic and post-materialistic values in 12 European countries.

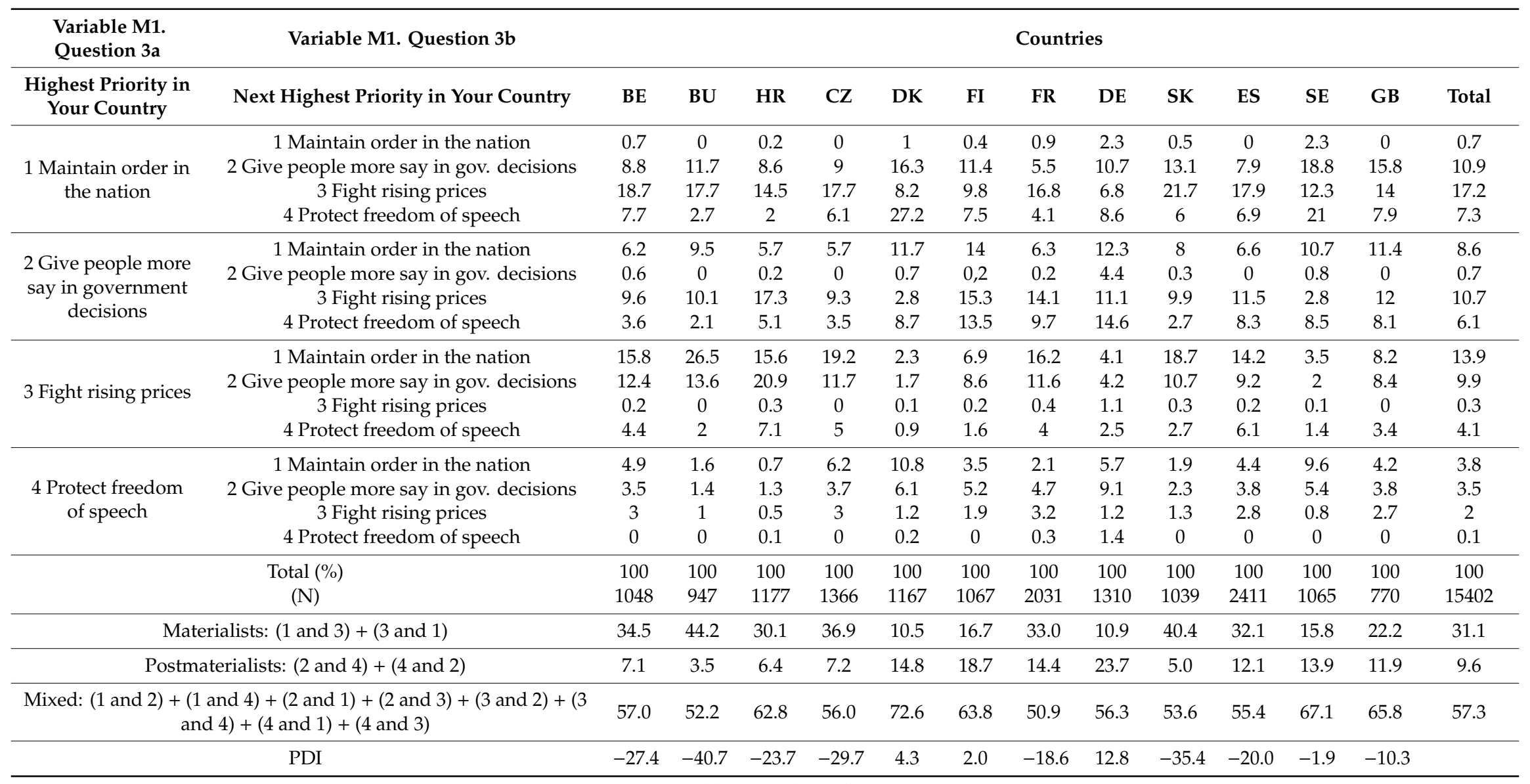

Source: Own elaboration through ISSP 2010. 
At the head of postmaterialistic values is Germany (DE) with an PDI of $12.8 \%$, followed by the Nordic countries, Denmark with $4.3 \%$, Finland (FI) with $2 \%$ and Sweden (SE) with $-1.9 \%$. At the other end of the scale is Bulgaria (BU) with $-40.7 \%$, Slovakia (SK) with $-35.4 \%$, Czech Republic (RZ) with $-29.7 \%$ and Belgium with $-27.4 \%$. Eastern countries show the most extreme values towards materialism, confirming the hypotheses developed by Inglehart of scarcity and socialization that align with the shift from materialism to post-materialism.

\subsection{Hypothesis $H 1$}

The correlation of the postmaterialism index (PDI) with the other variables of the ISSP2010: Environment with respect to environmental awareness and attitude is shown in Table 10.

In the analysis of results between variable M1 (PDI) and the other variables extracted from the ISSP2010: Environment III, it is necessary to highlight some issues.

Environmental awareness (A1, A2, A3, A4 and A5). It is established that there is a significant and direct correlation between the PDI and the following variables: A3 $\left(0.660^{* *}\right.$, willingness to pay higher prices for environmental protection), A4 $\left(0.610^{*}\right.$, willingness to pay more taxes for environmental protection) and A5 $\left(0.786^{* *}\right.$, willingness to lower the standard of living for environmental protection). For the less specific questions in this block, A1 (0.345, level of environmental concern) and A2 ( -0.417 , greater concern for the environment and not for prices or employment) the correlation is weak and not significant $(>0.05)$. Three of the five variables obtain significant results of direct (positive) and significant correlation with the PDI. The two variables that are not sufficiently significant correspond to two more general questions, and in the case of variable A2, which compares environmental protection with employment and price increases, it should be noted that the survey was conducted between 2010 and 2011, where the effects of the crisis were very present. The H1 hypothesis is not rejected, a more postmodern society presents a greater environmental conscience. However, other interesting conclusions can be drawn from this same table.

In a more detailed analysis, the Nordic countries and Germany, which show the highest PDIs, clearly indicate a greater concern for the environment, are more willing to pay higher prices to protect the environment (A3), pay more taxes (A4) and even lower their standard of living after the environment (A5). The higher postmaterialistic values in these countries corroborate Inglehart's hypotheses on the theory of scarcity and the theory of socialization. Does it mean that this greater concern for the environment would encourage them to use more sustainable transport? In order to be able to answer this question, we must investigate a little further using the second hypothesis.

Regarding the variables A6, A7 and A8, where citizens are asked about air pollution produced by the automobile (A6), industries (A7) and agriculture (A8), there is no significant correlation with the postmaterialism index (PDI).

If we analyze the data shown in Table 11, a more modern vehicle fleet, with more efficient technologies and a greater penetration of alternative fuels, may cause the population to begin not to worry about this type of pollution with respect to less ecological countries in this regard, although this cannot be affirmed with the data used in this study.

Something that does surprise with respect to these variables on pollutants (A6, A7 and A8) is the appreciated difference between what the Europeans of these 12 countries think about the most polluting practices and what actually happens. For $72 \%$ of the Europeans surveyed, the pollution produced by industry is extremely dangerous or very dangerous, followed by agriculture with $66.3 \%$ and thirdly cars with 50\%. The European Environment Agency (EEA) details in its Environmental Indicator Report (2014) which are the most harmful substances and which agents are the generators of pollution. Contamination by CO and NOX has its most polluting agent in transport. In relation to PM10 and PM2.5 particles, industry is responsible for most of the pollution that occurs, as is the case with SOx pollution. As can be seen, the perception of Europeans does not coincide with reality. Measures of environmental awareness and knowledge are necessary to promote sustainable transport. 
Table 10. Correlation index of postmaterialism and environmental variables. ISSP 2010: Environment III.

\begin{tabular}{|c|c|c|c|c|c|c|c|c|c|c|c|c|c|c|}
\hline & Statistics & M1 & A1 & A2 & A3 & A4 & A5 & A6 & A7 & A8 & A9 & A10 & A11 & A12 \\
\hline \multirow{2}{*}{ M1 } & Pearson C. & 1 & 0.345 & -0.417 & 0.660 * & 0.610 * & $0.786^{* *}$ & -0.516 & -0.344 & -0.412 & 0.644 * & 0.385 & 0.548 & $0.638^{*}$ \\
\hline & Bilateral Sig & & 0.273 & 0.177 & 0.019 & 0.035 & 0.002 & 0.086 & 0.273 & 0.183 & 0.024 & 0.216 & 0.065 & 0.026 \\
\hline \multirow{2}{*}{$\mathrm{A} 1$} & Pearson C. & 0.345 & 1 & 0.373 & 0.492 & 0.301 & 0.458 & -0.442 & -0.233 & -0.246 & 0.402 & 0.096 & 0.361 & 0.354 \\
\hline & Bilateral Sig & 0.273 & & 0.233 & 0.104 & 0.342 & 0.135 & 0.150 & 0.466 & 0.442 & 0.195 & 0.766 & 0.248 & 0.260 \\
\hline \multirow{2}{*}{$\mathrm{A} 2$} & Pearson C. & -0.417 & 0.373 & 1 & -0.407 & -0.463 & -0.467 & -0.136 & -0.010 & 0.019 & -0.157 & -0.281 & 0,010 & -0.273 \\
\hline & Bilateral Sig & 0.177 & 0.233 & & 0.189 & 0.130 & 0.126 & 0.673 & 0.975 & 0.954 & 0.627 & 0.376 & 0,974 & 0.391 \\
\hline \multirow{2}{*}{ A3 } & Pearson C. & 0.660 * & 0.492 & $-0,407$ & 1 & 0.909 ** & $0.767^{\text {** }}$ & -0.444 & -0.453 & -0.321 & $0.612 *$ & 0.345 & 0.369 & $0.827^{* *}$ \\
\hline & Bilateral Sig & 0.019 & 0.104 & 0.189 & & 0.000 & 0.004 & 0.148 & 0.139 & 0.309 & 0.035 & 0.273 & 0.237 & 0.001 \\
\hline \multirow{2}{*}{ A4 } & Pearson C. & 0.610 * & 0.301 & -0.463 & $0.909^{* *}$ & 1 & 0.619 * & -0.370 & -0.579 * & -0.404 & 0.423 & 0.223 & 0.054 & $0.759^{* *}$ \\
\hline & Bilateral Sig & 0.035 & 0.342 & 0.130 & 0.000 & & 0.032 & 0.237 & 0.049 & 0.193 & 0.171 & 0.485 & 0.868 & 0.004 \\
\hline \multirow{2}{*}{ A5 } & Pearson C. & $0.786^{* *}$ & 0.458 & -0.467 & 0.767 ** & $0.619 *$ & 1 & -0.419 & -0.253 & -0.299 & $0.777^{* *}$ & 0.108 & 0.510 & 0.670 * \\
\hline & Bilateral Sig & 0.002 & 0.135 & 0.126 & 0.004 & 0.032 & & 0.175 & 0.427 & 0.346 & 0.003 & 0.739 & 0.090 & 0.017 \\
\hline \multirow{2}{*}{ A6 } & Pearson C. & -0.516 & -0.442 & -0.136 & -0.444 & -0.370 & -0.419 & 1 & $0.835^{* *}$ & $0.807^{* *}$ & $-0.667^{*}$ & -0.129 & -0.523 & -0.710 ** \\
\hline & Bilateral Sig & 0.086 & 0.150 & 0.673 & 0.148 & 0.237 & 0.175 & & 0.001 & 0.002 & 0.018 & 0.689 & 0,081 & 0.010 \\
\hline \multirow{2}{*}{ A7 } & Pearson C. & -0.344 & -0.233 & -0.010 & -0.453 & $-0.579 *$ & -0.253 & $0.835^{* *}$ & 1 & $0.849^{* *}$ & -0.428 & -0.026 & -0.092 & -0.660 * \\
\hline & Bilateral Sig & 0.273 & 0.466 & 0.975 & 0.139 & 0.049 & 0.427 & 0.001 & & 0.000 & 0.166 & 0.936 & 0.776 & 0.019 \\
\hline \multirow{2}{*}{ A8 } & Pearson C. & -0.412 & -0.246 & 0.019 & -0.321 & -0.404 & -0.299 & $0.807^{* *}$ & $0.849^{* *}$ & 1 & -0.574 & 0.141 & -0.258 & -0.549 \\
\hline & Bilateral Sig & 0.183 & 0.442 & 0.954 & 0.309 & 0.193 & 0.346 & 0.002 & 0.000 & & 0.051 & 0,662 & 0.418 & 0.064 \\
\hline \multirow{2}{*}{ A9 } & Pearson C. & 0.644 * & 0.402 & -0.157 & 0.612 * & 0.423 & $0.777^{* *}$ & $-0.667^{*}$ & -0.428 & -0.574 & 1 & -0.024 & 0.791 ** & $0.745^{* *}$ \\
\hline & Bilateral Sig & 0.024 & 0.195 & 0.627 & 0.035 & 0.171 & 0.003 & 0.018 & 0.166 & 0.051 & & 0.942 & 0.002 & 0.005 \\
\hline \multirow{2}{*}{ A10 } & Pearson C. & 0.385 & 0.096 & -0.281 & 0.345 & 0.223 & 0.108 & -0.129 & -0.026 & 0.141 & -0.024 & 1 & 0.370 & 0.311 \\
\hline & Bilateral Sig & 0.216 & 0.766 & 0.376 & 0.273 & 0.485 & 0.739 & 0.689 & 0.936 & 0.662 & 0.942 & & 0.236 & 0.326 \\
\hline \multirow{2}{*}{ A11 } & Pearson C. & 0.548 & 0.361 & 0.010 & 0.369 & 0.054 & 0.510 & -0.523 & -0.092 & -0.258 & $0.791^{* *}$ & 0.370 & 1 & 0.544 \\
\hline & Bilateral Sig & 0.065 & 0.248 & 0.974 & 0.237 & 0.868 & 0.090 & 0.081 & 0.776 & 0.418 & 0.002 & 0.236 & & 0.068 \\
\hline \multirow{2}{*}{ A12 } & Pearson C. & 0.638 * & 0.354 & -0.273 & $0.827^{* *}$ & 0.759 ** & 0.670 * & $-0.710^{* *}$ & $-0.660 *$ & -0.549 & $0.745^{* *}$ & 0.311 & 0.544 & 1 \\
\hline & Bilateral Sig & 0.026 & 0.260 & 0.391 & 0.001 & 0.004 & 0.017 & 0.010 & 0.019 & 0.064 & 0.005 & 0.326 & 0.068 & \\
\hline
\end{tabular}

Note: ${ }^{*}$ Correlation is significant at level 0.05 (bilateral). ${ }^{* *}$ Correlation is significant at level 0.01 (bilateral). Source: Own elaboration through ISSP 2010. 
Table 11. Europeans' perception of air pollution from cars.

\begin{tabular}{cccccccc}
\hline \multicolumn{2}{c}{ VARIABLE A6: In General, do You Think That Air Pollution Caused by Cars is ... ? Values in (\%) } \\
\hline Countries & $\begin{array}{c}\text { Extremely } \\
\text { Dangerous }\end{array}$ & $\begin{array}{c}\text { Very } \\
\text { Dangerous }\end{array}$ & $\begin{array}{c}\text { Somewhat } \\
\text { Dangerous }\end{array}$ & $\begin{array}{c}\text { Not Very } \\
\text { Dangerous }\end{array}$ & $\begin{array}{c}\text { Not } \\
\text { Dangerous }\end{array}$ & Total & (N) \\
\hline Belgium & 8.0 & 26.1 & 52.0 & 12.8 & 1.1 & 100 & 1083 \\
\hline Bulgaria & 25.8 & 37.6 & 29.8 & 5.9 & 0.9 & 100 & 984 \\
\hline Croatia & 22.5 & 37.7 & 32.8 & 6.8 & 0.2 & 100 & 1203 \\
\hline Czech Republic & 13.1 & 41.3 & 34.8 & 9.8 & 1.1 & 100 & 1401 \\
\hline Denmark & 10.1 & 29.9 & 50.1 & 9.7 & 0.2 & 100 & 1240 \\
\hline Finland & 3.4 & 23.7 & 54.3 & 17.6 & 1.1 & 100 & 1184 \\
\hline France & 10.9 & 25.9 & 51.8 & 10.7 & 0.7 & 100 & 2192 \\
\hline Germany & 11.9 & 41.0 & 39.1 & 7.5 & 0.5 & 100 & 1341 \\
\hline Slovakia & 24.6 & 48.3 & 23.0 & 3.9 & 0.2 & 100 & 1144 \\
\hline Spain & 13.9 & 54.6 & 27.9 & 3.3 & 0.4 & 100 & 2531 \\
\hline Sweden & 9.4 & 34.6 & 46.8 & 9.1 & 0.2 & 100 & 1157 \\
\hline United Kingdom & 8.4 & 21.2 & 53.3 & 15.9 & 1.2 & 100 & 892 \\
\hline Total countries & 13.3 & 36.6 & 40.6 & 8.9 & 0.6 & 100 & 16,352 \\
\hline Standard desviation & 7.1 & 10.3 & 11.3 & 4.4 & 0.4 & & \\
\hline & & Source: Own elaboration through ISSP 2010. & & &
\end{tabular}

The last group of variables corresponding to ISSP2010, A9, (frequency of recycling in the home), A10 (purchase of ecological products), A11 (do not use the car for environmental reasons) and A12 (belong to an ecological group), form the pro-environmental behaviour module. In general it can be affirmed that post-materialistic values incline towards pro-environmental behaviour, although in this case it should be noted that questions about the frequency of recycling or the purchase of ecological products will depend very much on the infrastructures and opportunities that surround the individual. Both the frequency of recycling in the home and the membership of an environmental organisation have a positive correlation and bilateral significance with respect to the PDI, with the most post-material countries showing a more marked pro-environmental behaviour.

\subsection{Hypothesis $\mathrm{H} 2$}

With regards to the results taken from the second survey used, Eurobarometer 406-79.4, a sustainable transport index has been constructed, grouping together the percentage of all journeys made by sustainable means, that is, excluding the private car or motorcycle. In order to adapt to the survey used in the 12 societies, sustainable behaviour is understood as that individual who, although using his own car or motorcycle, does so at most once a week, in such a way that functional trips (work, study) in the daily life of the individual are excluded. The STI ranges from 0 to 100, with higher indicating greater use of sustainable transport. See Figure 3 below.

Respondents in Bulgaria, the Czech Republic, Slovakia, and Spain have the highest STI values. As already mentioned, it is risky to draw firm conclusions regarding the use of collective transport without knowing whether the individual has the possibility to use sustainable transport, or only has the choice of his own vehicle for his daily tasks; it is also possible that the respondent does not have the financial capacity to purchase a car, so that when travelling by motorised means he needs collective transport (captive user). Even so, it is necessary to comment how the post-materialist countries, which also have a greater environmental awareness, detailed above, do not stand out for their sustainable mobility, development does not necessarily bring better dwellings [54,67]. 


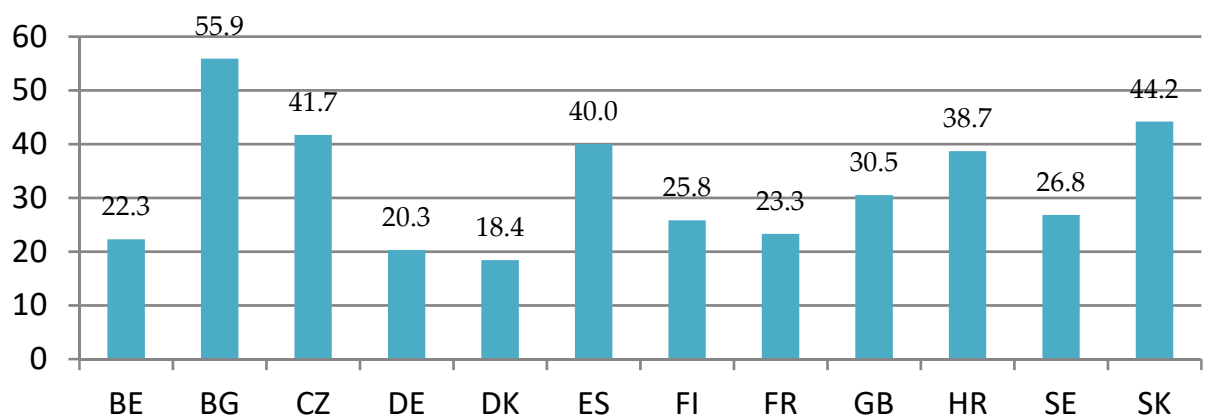

Figure 3. Sustainable transport index in 12 European countries. Source: own elaboration through Eurobarometer 406-79.4 (2013) Belgium (BE), Bulgaria (BG), Croatia (HR), Czech Republic (CZ), Denmark (DK), Finland (FI), France (FR), Germany (DE), Slovakia (SK), Spain (ES), Sweden (SE) and United Kingdom (GB).

Table 12 showing the correlation between STI and environmental awareness, extracted from Eurobarometer 409-79.4, indicates in a first exploration how the bilateral correlation is not significant in most cases between STI and the rest of the variables. There are even cases such as the one between STI and P1 (climate change as a priority for the EU) that comes out negative, this would mean that increased use of sustainable transport does not correspond to users' feelings that climate change should be a priority for the EU.

Table 12. Correlation between environmental awareness and sustainable transport.

\begin{tabular}{|c|c|c|c|c|c|c|c|c|}
\hline & & STI & P1 & P2 & P3 & $\mathbf{P 4}$ & P5 & P6 \\
\hline \multirow{2}{*}{ STI } & Pearson Correlation & 1 & $-0.594 *$ & -0.029 & 0.419 & 0.628 * & 0.571 & -0.562 \\
\hline & Bilateral Sig & & 0.042 & 0.928 & 0.175 & 0.029 & 0.052 & 0.057 \\
\hline \multirow[b]{2}{*}{$\mathrm{P} 1$} & Pearson Correlation & $-0.594^{*}$ & 1 & 0.382 & $-0.602 *$ & -0.618 * & -0.465 & 0.139 \\
\hline & Bilateral Sig & 0.042 & & 0.221 & 0.038 & 0.032 & 0.128 & 0.666 \\
\hline \multirow{2}{*}{$\mathrm{P} 2$} & Pearson Correlation & -0.029 & 0.382 & 1 & -0.005 & 0.043 & 0.071 & -0.031 \\
\hline & Bilateral Sig & 0.928 & 0.221 & & 0.988 & 0.893 & 0.825 & 0.924 \\
\hline \multirow{2}{*}{ P3 } & Pearson Correlation & 0.419 & $-0.602 *$ & -0.005 & 1 & $0.885^{* *}$ & $0.893^{* *}$ & -0.332 \\
\hline & Bilateral Sig & 0.175 & 0.038 & 0.988 & & 0.000 & 0.000 & 0.292 \\
\hline \multirow{2}{*}{$\mathrm{P} 4$} & Pearson Correlation & $0.628 *$ & -0.618 * & 0.043 & $0.885^{* *}$ & 1 & $0.950 * *$ & -0.441 \\
\hline & Bilateral Sig & 0.029 & 0.032 & 0.893 & 0.000 & & 0.000 & 0.151 \\
\hline \multirow{2}{*}{ P5 } & Pearson Correlation & 0.571 & -0.465 & 0.071 & $0.893^{* *}$ & $0.950 * *$ & 1 & -0.418 \\
\hline & Bilateral Sig & 0.052 & 0.128 & 0.825 & 0.000 & 0.000 & & 0.176 \\
\hline \multirow[b]{2}{*}{ P6 } & Pearson Correlation & -0.562 & 0.139 & -0.031 & -0.332 & -0.441 & -0.418 & 1 \\
\hline & Bilateral Sig & 0.057 & 0.666 & 0.924 & 0.292 & 0.151 & 0.176 & \\
\hline
\end{tabular}

Note: * Correlation is significant at level 0.05 (bilateral). ${ }^{* *}$ Correlation is significant at level 0.01 (bilateral). Source:

Own elaboration through Eurobarometer 406-79.4 (2013).

The $\mathrm{H} 2$ hypothesis is rejected; greater environmental awareness and behaviour does not imply greater use of sustainable transport. The correlation sought between variables P1 to P6 (environmental awareness) and the sustainable mobility habits obtained with the IST is not significant. There are many more conditioning factors that influence the modal choice of the citizen, and although societies are moving towards postmodern values and towards greater concern for the environment, it cannot be said that greater environmental concern is sufficient to change transport habits towards a more sustainable mode.

In any case, interesting results are obtained from this table. Countries with a higher STI (more walking, cycling or collective transport and less use of private vehicle) are those that appreciate urban traffic as a problem. Where urban traffic is not seen as a problem correspond to those with a lower STI. Figure 4 details the values found. 


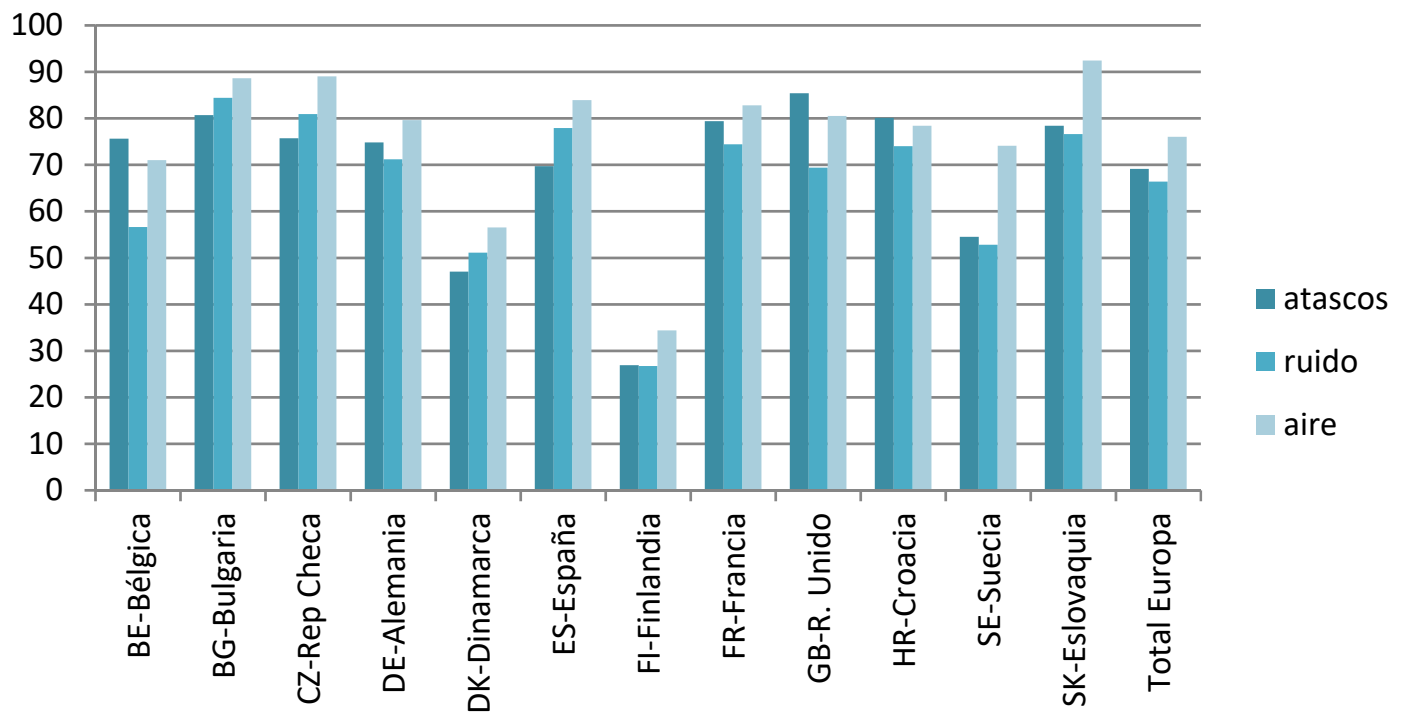

Figure 4. Opinion on the problems of cities. Source: Own elaboration through Eurobarometer 406-79.4 (2013).

Concern regarding traffic, acoustic pollution and air pollution of the Europeans of the 12 countries surveyed, reflected in the variables P3, P4 and P5, shows some harmony in the results between the majority of countries. Finland, Denmark and Sweden appear to be far less concerned about these three aspects of the city, which leads one to think that traffic jams in these populations are not as frequent as in the big cities of France, Spain or the United Kingdom, so the population does not see traffic as a problem. From there it can be extracted that noise and air quality in cities are also not major problems for these citizens.

With regard to variable P6 (responsible for reducing traffic in cities), all the countries surveyed except France point to the city authorities where they live as the maximum responsible for reducing traffic (P6), with values from $67 \%$ of Danes and Finns to $42 \%$ of Spaniards. Secondly, citizens themselves appear to be responsible for reducing traffic in cities.

\section{Conclusions}

The advance of society towards postmodern values implies a greater environmental awareness, a growing concern for the environment and a clear concern about the habitat that surrounds us and the influence we have on it. The protection of the environment is a global issue, with the inhabitants of large cities being one of the groups most adversely affected by environmental problems. Does this situation lead the citizen to be more aware of the importance of sustainable mobility?

The values of environmental awareness are high in the countries surveyed but must be differentiated between environmental awareness from a pro-environmental attitude. This is the case of countries such as Spain and Bulgaria, which although presenting high levels of environmental awareness, do not stand out from the rest of the countries by pro-environmental practices, presenting even the lowest levels; therefore, the fact that a nation presents high indices of environmental awareness, does not imply pro-environmental behaviour.

The less developed countries in the sample present less environmentally healthy attitudes than the more developed ones. In questions about economic efforts to protect the environment, countries such as Croatia, Bulgaria, the Czech Republic and Slovakia present themselves as unwilling. The Nordic countries in the sample, such as Finland, Sweden and Denmark, together with Germany, present the most collaborative attitudes in these assumptions.

The citizens' perception of the most polluting agents in the air does not coincide with the objective data on this phenomenon. It should be noted that in more developed countries the motor energy and age of the vehicle fleet is much more efficient in terms of pollutants than in other countries, 
hence the perception of vehicle pollution in Bulgaria or Slovakia offers much higher data than that of Nordic countries, which have demonstrated greater awareness and pro-environmental attitude towards sustainable transport. In countries such as Sweden and Denmark the use of hybrid, electric and other ecological systems is much more widespread than elsewhere.

Respondents living in places with higher traffic problems use sustainable transport more. This statement, which can be banal, is not so banal if the results are analysed. The countries most concerned about the environment, with more post-materialistic values and greater economic development have yielded somewhat surprising data. Finland is a clear example, its citizens do not consider traffic in cities to be a problem, nor do they consider noise or air pollution to be problematic in their cities. This is because they do not suffer from this kind of inconvenience, Nordic cities are at the tail end of urban pollution, so their inhabitants who do not have major traffic or pollution problems do not hesitate to use the car for everyday travel. On the other hand, they have a high degree of global environmental awareness, in values such as climate change and concern for the environment in general.

The personal development of citizens continues to be closely linked to the private vehicle, with which, if there are no barriers that hinder its use, they will continue to use it for their routine journeys instead of sustainable transport. It is important to note that countries with higher postmodern values are at the forefront in the use and development of alternative fuel vehicles, where local and state policies strongly support such measures. But pollution is not the only problem of cities, and future road traffic, even if considered to be zero emission, would still congest the city unless traffic in urban centres is limited and collective transport is promoted in the same way.

On the part of governments and the European Union, aggressive campaigns must be carried out to make citizens aware of the importance of sustainable transport. The cities of the most developed countries are full of containers to facilitate recycling, the citizen, has at home means to separate waste according to their nature and does so naturally, having assimilated the importance of recycling, although this takes some effort. On the other hand, the negative effects of unsustainable mobility on the city are still not clearly accepted. In this study it has been reflected how the most advanced countries are more aware of the environment, making use of recycling, belonging to environmental organizations and other pro-environmental behaviors; instead the private car is extracted from the pro-environmental equation, and it is necessary to change values towards sustainable transport.

Postmodern societies integrate the environment in their vital priorities, and the organization and citizen awareness will help to shape much more livable and healthy cities. Collective transport should be seen as a tool to improve our health, just as we take care of our diet or do physical exercise.

Supplementary Materials: The following are available online at http://www.mdpi.com/2071-1050/11/16/4274/s1: Questionnaires ISSP 2010 "Environment III" and Eurobarometer 406-79.4.

Author Contributions: Conceptualization, C.J.d.l.H.-R.; Methodology, C.J.d.l.H.-R., J.H.; Validation, J.H., C.J.d.l.H.-R.; Formal analysis, C.J.d.l.H.-R.; Investigation and Resources, C.J.d.l.H.-R., J.H.; Writing—original draft preparation, C.J.d.l.H.-R., J.H.; Writing—review and editing, C.J.d.l.H.-R., J.H.; Supervision, C.J.d.l.H.-R.; all authors read and approved the final manuscript.

Funding: This research received no external funding.

Acknowledgments: The authors are grateful to de anonymous reviewers for their valuable comments and suggestions.

Conflicts of Interest: The authors declare no conflict of interest.

\section{Appendix A. Methodological Note Weighting Age}

Suppose we would like to distinguish the age of respondents between those over 50 and those under 50 by asking whether they use public or private transport. If 400 surveys are conducted in that country, and 300 respondents are over 50 years old $(75 \%)$, and 100 are under $50(25 \%)$, so that the result of a question is not affected by the age of the respondents, the number of respondents over 50 who use public transport should be multiplied by 0.67 , while the number of respondents under 50 who use 
public transport should be multiplied by 2 . Thus the influence of age on the result of this question would be nullified. Another issue would be to carry out a demographic analysis to see what type of population resides in each city and to see which mode of transport is the most appropriate.

\section{References}

1. DESA 2018. Available online: https://www.un.org/development/desa/publications/2018-revision-of-worldurbanization-prospects.html (accessed on 30 June 2019).

2. United Nations. SDGs. Sustainable Development Goals. Available online: https://sustainabledevelopment. un.org/sdgs (accessed on 27 July 2019).

3. United Nations. New Urban Agenda. Available online: http://habitat3.org/the-new-urban-agenda/ (accessed on 27 July 2019).

4. Nikulina, V.; Simon, D.; Ny, H.; Baumann, H. Context-Adapted Urban Planning for Rapid Transitioning of Personal Mobility towards Sustainability: A Systematic Literature Review. Sustainability 2019, 11, 1007. [CrossRef]

5. Bericat, E. Sociología de la Movilidad Espacial: El Sedentarismo Nómada; Centro de Investigaciones Sociológicas: Madrid, Spain, 1994.

6. Hawley, A.H. Human Ecology: A Theory of Community Structure; UMI: New York, NY, USA, 1950; p. 346.

7. Real, J.E. Escalamiento Multidimensional; Ibérica Gráphics: Madrid, Spain, 2001.

8. Newman, P. Peak car use-What does it mean for urban design and planning? Proc. Inst. Civ. Eng. Urban Des. Plan. 2012, 165, 197-200. [CrossRef]

9. Driscoll, P.A.; Theodórsdóttir, A.H.; Richardson, T.; Mguni, P. Is the Future of Mobility Electric? Learning from Contested Storylines of Sustainable Mobility in Iceland. Eur. Plan. Stud. 2012, 20, 627-639. [CrossRef]

10. Newman, P.W. Transport infrastructure and sustainability: A new planning and assessment framework. Smart Sustain. Built Environ. 2015, 4, 140-153.

11. Cooley, C.H. The Theory of Transportation. Publ. Am. Econ. Assoc. 1894, 9, 13-148.

12. Ullan, F.J. Sociología Urbana: De Marx y Engels a las Escuelas Postmodernas; Centro de Investigaciones Sociológicas: Madrid, Spain, 2014.

13. Halbwachs, M. Les plans d'extension et dámenagement de París avant le XIX e siècle. Paris Urb. 1920, 2, 3-28.

14. Benjamín, W. Libro de los Pasajes; Tiedemann, R., Ed.; Akal: Madrid, Spain, 2005.

15. Cerdá, I. Teoría General de la Urbanización y Aplicación de sus Principios y Doctrinas a la Reforma y Ensanche de Barcelona; Imprenta Española: Madrid, Spain, 1868.

16. Howard, E. Garden Cities of Tomorrow; Createspace: Scotts Valley, CA, USA, 2015.

17. Bonet, A. La Ciudad del Futuro; Realigraf, S.A., Ed.; Instituto de España: Madrid, Spain, 2009.

18. Urry, J. Inhabiting the Car. Sociol. Rev. 2006, 54 (Suppl. 1), 17-31. [CrossRef]

19. Freund, P.; Martin, G. The Ecology of the Automobile; Black Rose Books: Montreal, QC, Canada, $1993 ;$ p. 119.

20. Gorostiza Langa, S. El choque del automóvil con la ciudad: Entrevista con Alfonso Sanz. Ecol. Politica 2014, 47, 46-55.

21. Alonso, W. A theory of the urban land market. Pap. Reg. Sci. 1960, 6, 149-157. [CrossRef]

22. Zahavi, Y. Travel Time Budget and Mobility in Urban Areas; Federal Highway Administration, Department of Transportation: Washington, DC, USA, 1974.

23. Kumar, K. Prophecy and Progress: The Sociology of Industrial and Postindustrial Society; Penguin Books: Harmondsworth, UK, 1978; p. 71.

24. Banister, D. The trilogy of distance, speed and time. J. Transp. Geogr. 2011, 19, 950-959. [CrossRef]

25. Banister, D. The sustainable mobility paradigm. Transp. Policy 2008, 15, 73-80. [CrossRef]

26. Nykvist, B.; Whitmarsh, L. Multi-level analysis of sustainable mobility transitions: Niche development in the UK and Sweden. Technol. Forecast. Soc. Chang. 2008, 75, 1373-1387. [CrossRef]

27. Köhler, J.; Whitmarsh, L.; Nykvist, B.; Schilperoord, M.; Bergman, N. A transitions model for sustainable mobility. Ecol. Econ. Transdiscipl. J. Int. Soc. Ecol. Econ. 2009, 68, 2985-2995. [CrossRef]

28. Bi, Z.; Kan, T.; Mi, C.; Zhang, Y.; Zhao, Z.; Keoleian, G. A review of wireless power transfer for electric vehicles: Prospects to enhance sustainable mobility. Appl. Energy 2016, 179, 413-425. [CrossRef] 
29. Cervero, R.; Kockelman, K. Travel demand and the 3Ds: Density, diversity, and design. Transp. Res. Part Transp. Environ. 1997, 2, 199-219. [CrossRef]

30. Ewing, R.; Cervero, R. Travel and the Built Environment: A Meta-Analysis. J. Am. Plan. Assoc. 2010, 76, 265-294. [CrossRef]

31. Kenworthy, J. The eco-city: Ten key transport and planning dimensions for sustainable city development. Environ. Urban. 2006, 18, 67-85. [CrossRef]

32. Bertolini, L.; le Clercq, F. Urban Development without more Mobility by Car? Lessons from Amsterdam, a Multimodal Urban Region. Environ. Plan. A 2003, 35, 575-589. [CrossRef]

33. Banister, D. Cities, mobility and climate change. J. Transp. Geogr. 2011, 19, 1538-1546. [CrossRef]

34. Vergragt, P.; Brown, H. Sustainable mobility: From technological innovation to societal learning. J. Clean. Prod. 2007, 15, 1104-1115. [CrossRef]

35. Zhao, P.J. Sustainable urban expansion and transportation in a growing megacity: Consequences of urban sprawl for mobility on the urban fringe of Beijing. Habitat Int. 2010, 34, 236-243. [CrossRef]

36. Hull, A. Policy integration: What will it take to achieve more sustainable transport solutions in cities? Transp. Policy 2008, 15, 94-103. [CrossRef]

37. Hysing, E. Greening transport-explaining urban transport policy change. J. Environ. Policy Plan. 2009, 11, 243-261. [CrossRef]

38. Buehler, R.; Pucher, J. Sustainable Transport in Freiburg: Lessons from Germany's Environmental Capital. Int. J. Sustain. Transp. 2011, 5, 43-70. [CrossRef]

39. Curtis, C.; Scheurer, J. Planning for sustainable accessibility: Developing tools to aid discussion and decision-making. Prog. Plan. 2010, 74, 53-106. [CrossRef]

40. Sultana, S.; Salon, D.; Kuby, M. Transportation sustainability in the urban context: A comprehensive review. Urban Geogr. 2017, 40, 279-308. [CrossRef]

41. Banister, D.; Hickman, R. How to design a more sustainable and fairer built environment: Transport and communications. IEE Proc. Intell. Transp. Syst. 2006, 153, 276-291. [CrossRef]

42. Sá, N.L.; Gouveia, J.B. Sustainable mobility-Analysis of sustainable mobility measures in cities. WIT Trans. Ecol. Environ. 2010, 142, 157-168.

43. Ortúzar, J.; Willumsen, L. Modelos de Transporte; Universidad de Cantabria: Santander, Spain, 2008.

44. Hrelja, R. The Tyranny of Small Decisions. Unsustainable Cities and Local Day-to-Day Transport Planning. Plan. Theory Pract. 2011, 12, 511-524. [CrossRef]

45. Elmqvist, T.; Bai, X.; Frantzeskaki, N.; Grith, C.; Maddox, D.; McPhearson, T.; Parnell, S.; Romero-Lankao, P.; Simon, D.; Watkins, M. (Eds.) The Urban Planet: Knowledge towards Sustainable Cities; Cambidge University Press: New York, NY, USA, 2018; ISBN 978-1-107-19693-3.

46. Hull, A. Transport Matters: Integrated Approaches to Planning City-Regions; Routledge: London, UK, 2011; ISBN 020393878X.

47. Kenyon, S.; Rafferty, J.; Lyons, G. Social Exclusion and Transport in the UK: A Role for Virtual Accessibility in the Alleviation of Mobility-Related Social Exclusion? J. Soc. Policy 2003, 32, 317-338. [CrossRef]

48. Gobernado Arribas, R. Análisis de la movilidad recurrente intraurbana: Almería. Rev. Estud. Reg. 1985, 1, $29-58$.

49. Stryker, S.; Elias, C.; Gillies, J.; Riemer, S. Metropolis: Values in Conflict. Am. Sociol. Rev. 1965, 30, 634. [CrossRef]

50. Pinna, F.; Masala, F.; Garau, C. Urban Policies and Mobility Trends in Italian Smart Cities. Sustainability 2017, 9, 494. [CrossRef]

51. Yue, W.S.; Chye, K.K.; Hoy, C.W. Towards S mart mobility in urban spaces: Bus tracking and information application. AIP Conf. Proc. 2017, 1891, 201-245. [CrossRef]

52. Caughill, P. Volvo Says That They Will Stop Making Diesel Engines, Thanks to Tesla. Futurism, 18 May 2017.

53. Johannessen, M.; Berntzen, L. Smart Cities through Implicit Participation: Using Gamification to Generate Citizen Input for Public Transport Planning; IOS Press Ebooks: Amsterdam, The Netherlands, 2016.

54. Inglehart, R. Modernización y Posmodernización: El Cambio Cultural, Económico y Político en 43 Sociedades; Centro de Investigaciones Sociológicas: Madrid, Spain, 2000.

55. Díez Nicolás, J. Postmaterialismo y desarrollo económico en España. In Tendencias Mundiales de Cambio en los Valores Sociales y Políticos: Una Perspectiva Global; Nicolás, J.D., Inglehart, R., Eds.; Fundesco: Madrid, Spain, 1994; pp. 125-156. 
56. Herrera, M.; Gallego, D.; Pagés, S. Una nueva realidad en los sistemas de bienestar: El Tercer sector. In Evaluación y Calidad en las Organizaciones Públicas; Trinidad, A., Ed.; INAP: Madrid, Spain, 2000.

57. Bell, D. The Coming of Post-Industrial Society; Basics Books: New York, NY, USA, 1973.

58. Inglehart, R. The Silent Revolution; Princeton University Press: Princeton, NJ, USA, 1977; Chapter 5.

59. Dunlap, R.; Mertig, A. Global Environmental Concern: An Anomaly for Postmaterialism. Soc. Sci. Q. 1997, 78, 24-29.

60. Grendstad, G.; Per, S. Cultural Theory, Postmaterialism, and Environmental Attitudes. In Culture Matters, 1st ed.; Ellis, R., Ed.; Routledge: New York, NY, USA, 1997; Chapter 9.

61. ISSP Research Group. International Social Survey Programme: Environment III-ISSP 2010; ZA5500 Data File Version 3.0.0; GESIS Data Archive: Cologne, Germany, 2019. [CrossRef]

62. European Commission. Eurobarometer 79.4 (2013); ZA5852 Data File Version 4.0.0; TNS Opinion, Brussels [producer]; GESIS Data Archive: Cologne, Germany, 2017. [CrossRef]

63. Díez Nicolás, J.; En Elzo, J. España 2000, Entre el Localismo y la Globalidad; Universidad de Deusto, EDICIONES SM: Madrid, Spain, 2000; p. 285.

64. Picó, J.; Pérez Carreño, F. Modernidad y Postmodernidad, 1st ed.; 3a Reimp; Alianza: Madrid, Spain, 1998.

65. Smart, B. Modernity, Postmodernity and the Present. In Theories of Modernity and Postmodernity; Turner, B.S., Ed.; London Sage: London, UK, 1991.

66. Tormos, R. Valores postmaterialistas y aprendizaje político adulto. El cambio de valores intracohorte en Europa occidental. REIS 2012, 140, 89-120.

67. Lyon, D. Postmodernidad; Alianza Editorial: Madrid, Spain, 1996.

(C) 2019 by the authors. Licensee MDPI, Basel, Switzerland. This article is an open access article distributed under the terms and conditions of the Creative Commons Attribution (CC BY) license (http://creativecommons.org/licenses/by/4.0/). 